\title{
First record of the redclaw crayfish Cherax quadricarinatus (Von Martens, 1868) on the Iberian Peninsula
}

\author{
Andrés Arias ${ }^{1}$ and Antonio Torralba-Burrial ${ }^{2, *}$ \\ ${ }^{1}$ Dpto. Biología de Organismos y Sistemas, Universidad de Oviedo, Oviedo 33071, Spain. \\ 2 Instituto de Recursos Naturales y Ordenación del Territorio Indurot, Universidad de Oviedo, Mieres 33071, \\ Spain. \\ * Corresponding author: torralbaantonio@uniovi.es
}

Received: 10/08/19

Accepted: 03/12/19

\begin{abstract}
First record of the redclaw crayfish Cherax quadricarinatus (Von Martens, 1868) on the Iberian Peninsula

The spreading of non-indigenous crayfish species represents a major risk for freshwater ecosystems worldwide. They can influence several trophic levels, reach great abundances and carry foreign epibionts and parasites that may affect native fauna. The early detection and identification of the alien crayfish is crucial to avoid further problems once they are naturalized and/or they become invasive. Here we report the first occurrence of the Australian redclaw crayfish Cherax quadricarinatus on the Iberian Peninsula, constituting the westernmost record of the species in Europe. We present a comprehensive diagnosis and illustration of the species in order to facilitate its differentiation from the other crayfish species occurring in Iberia. Furthermore, we include brief notes on its biology and discuss plausible pathways of its introduction, its invasive potential and the possible impacts it may cause in native ecosystems.
\end{abstract}

Key words: Decapoda, crayfish, Parastacidae, alien species, exotic species, aquatic invasive species, Spain, freshwater ecosystem, biodiversity

\section{RESUMEN}

Primera cita del cangrejo de pinzas rojas Cherax quadricarinatus (Von Martens, 1868)) en la península ibérica

La expansión de especies alóctonas de cangrejos de río conlleva un gran riesgo para los ecosistemas de aguas continentales en todo el mundo. Estas especies pueden alterar varios niveles tróficos, alcanzar grandes abundancias y ser portadoras de epibiontes y patógenos que puedan afectar a la fauna nativa. La identificación y detección temprana de los cangrejos alóctonos es vital para evitar futuros problemas si éstas consiguen naturalizarse y desarrollar un comportamiento invasor. Aquí se presenta la primera cita del cangrejo australiano de pinzas rojas Cherax quadricarinatus en la península ibérica, la cual pasa a constituir su límite Oeste de distribución conocida en Europa. Se proporcionan una diagnosis e ilustración detallada de la especie para facilitar su correcta diferenciación de las otras especies de cangrejos de río presentes en Iberia. Además, se incluyen notas breves sobre su biología y se discuten las vias de introducción más probables, su potencial invasor y los posibles impactos que podría generar en los ecosistemas nativos.

Palabras clave: Decapoda, cangrejos de río, Parastacidae, especie alien, especie exótica, especie acuática invasora, España, ecosistema de agua dulce, biodiversidad 


\section{INTRODUCTION}

The introduction and spreading of non-indigenous species (NIS) of aquatic fauna, flora and microbes has caused and still causes, strong ecological impacts in freshwater environments worldwide (Ricciardi \& MacIsaac, 2011). Cumulative invasions have restructured freshwater communities in such a way that they are often dominated by the NIS, which are frequently involved in ecosystem disruption and biodiversity loss (Ricciardi \& MacIsaac, 2011). At this critical juncture, one of the macrofaunal groups that cause greater concern in inland aquatic ecosystems are crayfish (Astacida). Crayfish species are large freshwater invertebrates able to inhabit almost every type of water mass and develop important ecological roles as keystone or ecosystem engineer species (Pöckl et al., 2006). Furthermore, several crayfish species (e.g. the red swamp crayfish, Procambarus clarkii (Girard, 1852)) constitute a valuable food resource and support a considerable industry, being introduced for aquaculture purposes (i.e. astaciculture) or for bait by fishermen worldwide (Pöckl et al., 2006; Vedia \& Miranda, 2013).

Until now, five species of crayfish are known to reside on the Iberian Peninsula: the species complex of the white-clawed crayfish Austropotamobius pallipes (Lereboullet, 1858) / Austropotamobius italicus (Faxon, 1914), the red swamp crayfish, the signal crayfish Pacifastacus leniusculus (Dana, 1852), the spiny-check crayfish Orconectes limosus (Rafinesque, 1817) and the yabby Cherax destructor (Clark, 1936) (Benejam et al., 2011; Vedia \& Miranda, 2013). The status of the white-clawed crayfish species complex is widely discussed in the scientific community. Some authors consider that the Iberian populations were the result of human translocations from northwestern Italy dating back to the $16^{\text {th }}$ century (e.g. Clavero et al., 2016), while others argue that it is an indigenous species from Iberia (e.g. Matallanas et al., 2016). The remaining four species were introduced either intentionally or accidentally during the late $20^{\text {th }}$ century

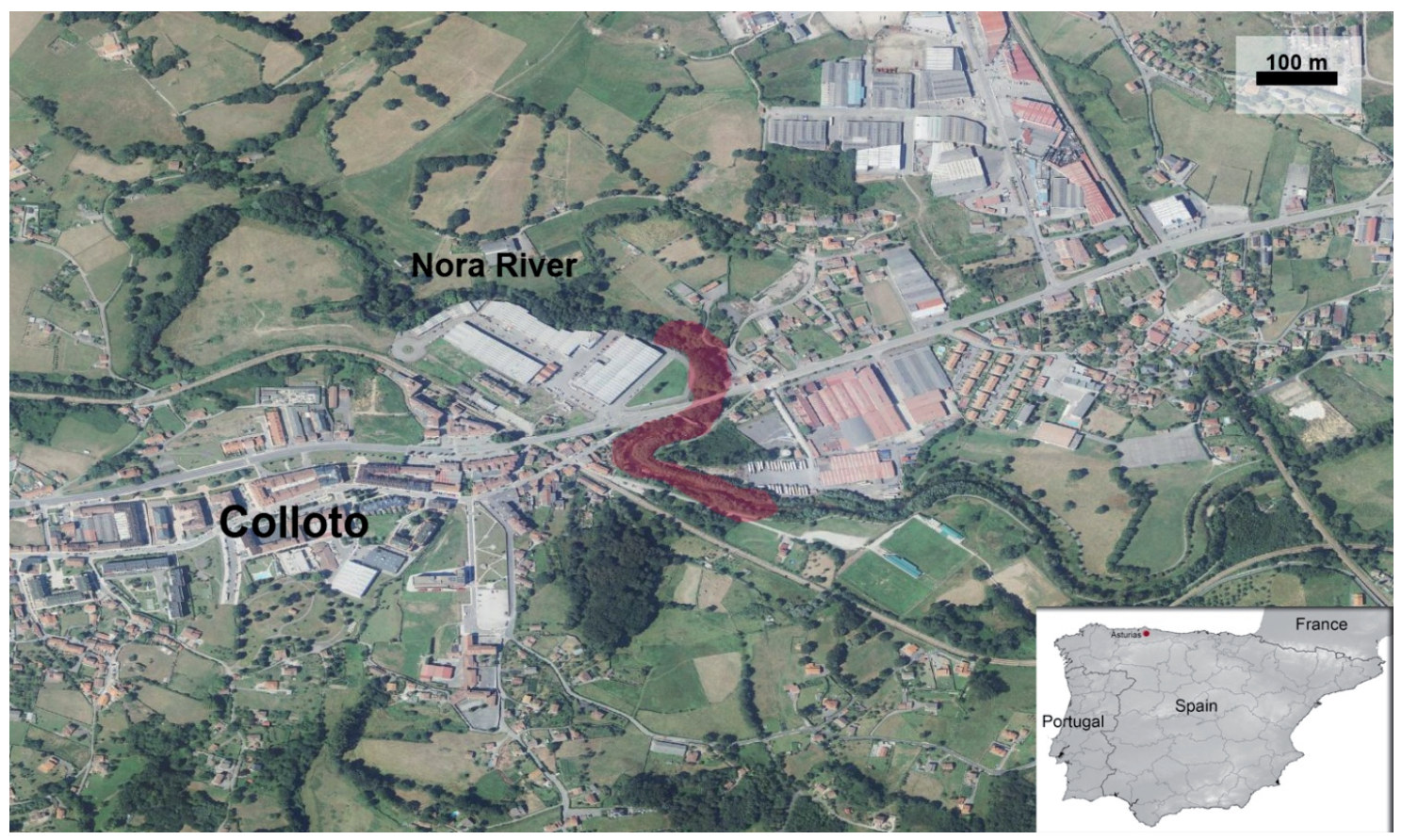

Figure 1. Location of detected population of Cherax quadricarinatus, in red, on the Nora River (Asturias, Spain) (Orthophoto PNOA, National Cartographic System). Localización de la población detectada de Cherax quadricarinatus, en rojo, en el río Nora (Asturias, España). (Ortofoto PNOA, Sistema Cartográfico Nacional). 
(Benejam et al., 2011; Pöckl et al., 2006; Vedia \& Miranda, 2013; Oficialdegui et al., 2019).

As part of a series of monitoring projects aimed to catalogue the NIS from the Principado de Asturias and border regions (northern Spain), a total of four species of freshwater crayfish belonging to four genera were identified. Among them, one species belonging to the Australian genus Cherax was found. This species was consistent with the diagnosis of the redclaw crayfish Cherax quadricarinatus (Von Martens, 1868), and constitutes the first record of the species on the Iberian Peninsula, increasing to six the number of crayfish species in Iberian inland waters. Here we present a detailed description and illustration of the species, highlighting the main diagnostic characters that allow us to distinguish the redclaw crayfish from the other crayfish species presented on the Iberian Peninsula. Furthermore, we discuss its introduction pathways to Iberia as well as the possible impacts that the redclaw crayfish may generate in the receiving ecosystems, according with their ecological requirements, temperature range and species detected in the area.

\section{MATERIALS AND METHODS}

Sampling was conducted at Nora River $\left(43^{\circ} 22^{\prime}\right.$ $\mathrm{N}, 5^{\circ} 47^{\prime} \mathrm{W}$, elevation: $160 \mathrm{~m}$, Colloto, Oviedo, Asturias, Spain). Nora River is a siliceous Cantabrian-Atlantic river, heavily modified in this reach (type R-T21-HM), with a moderate ecological status and a good chemical status, according with the Hydrological Plan of the Western Cantabrian River Basin (RD 1/2016). The river runs East-West through the central area of Asturias, with a meandering channel and very small slopes (approx. $240 \mathrm{~m}$ of unevenness along its $78 \mathrm{~km}$ length). Nora River crosses agricultural, industrial and periurban areas, with an intense urbanization nearby due to its proximity to the Capital city of Asturias (Oviedo). Sampling location constitutes a periurban reach around Oviedo, easily accessed by car, with a greenway in the right riverbank and recreational facilities and outdoors bars nearby (Fig. 1). Water physicochemical parameters of the Nora River station in the nearest point of the Superficial Water Control
Network (CEMAS) between 2009-2013 shown a temperature range between 7.8 to $20.4{ }^{\circ} \mathrm{C}$ (Confederación Hidrográfica del Cantábrico, station CHC2099 Lugones).

Crayfish specimens were collected by hand picking and Surber sampler. We first collected the redclaw crayfish in September 2013. Subsequent surveys at the same location were successful in detecting the species in June 2015, August 2016 and May 2017, but unsuccessful in November-December 2018 (Table 1). Collected specimens were preserved in $70 \%$ ethanol and were examined under both dissecting stereomicroscope and compound light microscope. Temporary glycerol slides of pereopods, pleopods, gills and other appendages were used for detailed examination of possible epibionts and parasites. Fifteen specimens of red swamp and signal crayfishes from the same locality were examined as comparative material. The collected specimens are deposited in the BOS Arthropod Collection of the Departamento de Biología de Organismos y Sistemas of the Oviedo University (data digitized will be available in the Global Biodiversity Information Facility according with the general BOS Collection workflow described in Torralba-Burrial \& Ocharan, 2013). Photomicrographs were taken with a Canon PowerShot SX30 IS camera with a Raynox DCR-250 lens.

\section{RESULTS AND DISCUSSION}

\section{Species diagnosis and description of Iberian specimens}

This diagnosis is based upon examined specimens (Fig. 2; Table 1) and bibliographic data (Pöckl et al., 2006; Holdich, 2009). The redclaw is a big crayfish, growing up to $35 \mathrm{~cm}$ in length at optimal conditions. Its rostrum is long and well developed (Fig. 2A, B, D-F and I), with a prominent acumen with borders more or less parallel that bear three pairs of short lateral spines each (Fig, 2B, E); also it extends posteriorly into the anterior carapace as two keels (Fig. 2A, C, D and I) and lacks a median carina. The redclaw crayfish has a smooth body surface with one pair of long post-orbital ridges forming two additional keels on the anterior carapace (Fig. 2A, C, D and 

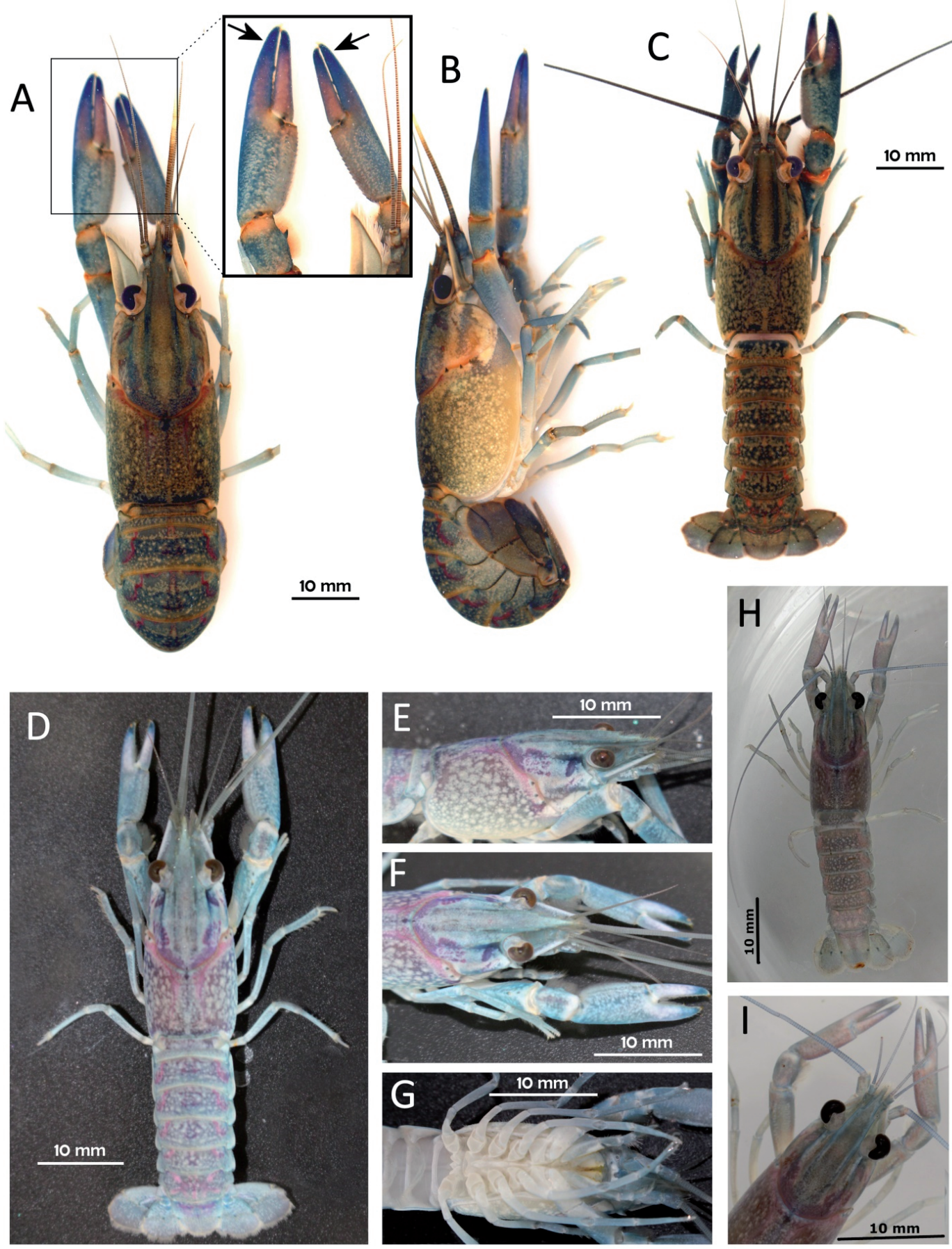

Figure 2. Photographs of live specimens of Cherax quadricarinatus from the study area, Nora River, Asturias, northern Spain. Alargest specimen $(89 \mathrm{~mm})$, dorsal view; B-same, lateral view; C-specimen of $80 \mathrm{~mm}$, lateral view; D- largest juvenile (56 mm), dorsal view; E-G same specimen, detailed view of anterior end in lateral view, rostrum and chelae and ventral view respectively; Hsmallest juvenile $(48 \mathrm{~mm})$, dorsal view; I- same, detailed view of rostrum and chelae. Fotografias de ejemplares vivos de Cherax quadricarinatus procedentes del área de estudio, río Nora, Asturias, norte de España. A-ejemplar más grande encontrado (89 mm) en vista dorsal; $B$ - mismo ejemplar en vista lateral; $C$ - ejemplar de $80 \mathrm{~mm}$ en vista lateral; $D$-juvenil más grande (56 mm) en vista dorsal; $E-G$ vistas detalladas del mismo ejemplar de la parte anterior en vista lateral, el rostro y las pinzas y la parte ventral respectivamente; $H$-juvenil más pequeño $(48 \mathrm{~mm})$ en vista dorsal; I-vista detallada del rostro y las pinzas del mismo ejemplar. 
I); and the spines of the carapace shoulder are behind the cervical groove. The pleopods of the first abdominal segment are absent (Fig. 2G). The dorsal surface of the telson lacks medial spines and its posterior part is membranous. The chela is smooth and narrow and the inner margin of the fixed finger (propodus) is longer than the moveable finger (dactylus) (Fig. 2A, see detail); two distinct spines are present on the upper edge of the cheliped coxa. The body color of adult specimens is usually dark blue mottled with beige and red/brown spots, with red leg joints (Fig. 2A-C). The juveniles color pattern ranges from light blue to light gray, mottled in white with whitish leg joints (Fig. 2D-I). Adult males are characterized by a soft, red colored patch on the outer margin of the propodus.

Iberian specimens ranged in total length (from the rostrum to the end of the telson) from $48 \mathrm{~mm}$ to $89 \mathrm{~mm}($ Mean $=65.43 ; \mathrm{SD}=15.45 ; \mathrm{N}=7)$. The three smallest specimens, of 48,50 and 56 $\mathrm{mm}$ long (Fig. 2D-I), were collected together in September 2013 and the largest one (i.e. $89 \mathrm{~mm}$ long, Fig. 2A and 2B) was the only specimen found in August 2016. Vázquez (2003) correlated the cephalothorax length with the potential mature stage of the redclaw crayfish, showing that the smallest mature male and female were of $17 \mathrm{~mm}$ and $24.5 \mathrm{~mm}$ respectively. Thus, according to this author all specimens found in the Nora river could be potentially mature and therefore reproductively active, if environmental conditions allow it. None of the three females collect- ed (Table 1) carried eggs and males have not mature coloration.

Regarding to the proportions among the three species of crayfishes that occur sympatrically in the Nora river, the red swamp crayfish was dominant in September 2013, being ten times more abundant than the remaining other two species. However, their proportions varied among years, in 2015 and 2016 the red swamp crayfish was nearly equidominant with the signal crayfish and both were 8 to 9 times more abundant that the redclaw crayfish; by contrast in May 2017 the proportions changed considerably, being the signal crayfish twice as abundant as the red swamp crayfish and both species were 30 and 15 times (respectively) more common that the redclaw crayfish.

Cherax crayfishes can be easily distinguished from the remaining crayfish present in Iberia by the inner edge of the propudus, which is longer than the dactylus (Fig. 2A) and the absence of pleopods from the first abdominal segment (Fig. 2G). Other differences together with a pictorial key can be found in Holdich (2009) and Pöckl et al. (2006). The redclaw crayfish differs from the yabby by the lack of a mat of setae along the proximal cutting edge of chelae (present in the yabby); the presence of lateral spines on the rostrum (absent in the yabby) and by bearing four keels on the anterior dorsal part of the carapace (only two keels in the yabby) (Holdich, 2009; Pöckl et al., 2006; Souty-Grosset et al., 2006).

Table 1. Redclaw crayfish Cherax quadricarinatus specimens collected at Nora River (Asturias). Especimenes de cangrejo de pinzas rojas Cherax quadricarinatus recolectados en el río Nora (Asturias).

\begin{tabular}{|c|c|c|c|c|c|c|}
\hline Specimen & $\begin{array}{l}\text { Collection } \\
\text { Date }\end{array}$ & Sex & $\begin{array}{l}\text { Total } \\
\text { length } \\
(\mathrm{mm})\end{array}$ & $\begin{array}{l}\text { Cephalothorax } \\
\text { length }(\mathrm{mm})\end{array}$ & $\begin{array}{l}\text { Sampling } \\
\text { method }\end{array}$ & Coordinates \\
\hline 1 & $/ 09 / 2013$ & male & 48 & 24 & Surber net & $43^{\circ} 22^{\prime} 44^{\prime \prime} \mathrm{N}-5^{\circ} 47^{\prime} 19^{\prime \prime} \mathrm{W}$ \\
\hline 2 & $/ 09 / 2013$ & male & 50 & 25 & Surber net & $43^{\circ} 22^{\prime} 44^{\prime \prime} \mathrm{N}-5^{\circ} 47^{\prime} 19^{\prime \prime} \mathrm{W}$ \\
\hline 3 & $/ 09 / 2013$ & male & 56 & 26 & Surber net & $43^{\circ} 22^{\prime} 44^{\prime \prime} \mathrm{N}-5^{\circ} 47^{\prime} 19^{\prime \prime} \mathrm{W}$ \\
\hline 4 & $/ 06 / 2015$ & male & 59 & 26 & hand picking & $43^{\circ} 22^{\prime} 43^{\prime \prime} \mathrm{N}-5^{\circ} 47^{\prime} 22^{\prime \prime} \mathrm{W}$ \\
\hline 5 & $/ 06 / 2015$ & female & 70 & 33 & hand picking & $43^{\circ} 22^{\prime} 43^{\prime \prime} \mathrm{N}-5^{\circ} 47^{\prime} 22^{\prime \prime} \mathrm{W}$ \\
\hline 6 & $/ 08 / 2016$ & female & 89 & 43 & hand picking & $43^{\circ} 22^{\prime} 42^{\prime \prime} \mathrm{N}-5^{\circ} 47^{\prime} 21^{\prime \prime} \mathrm{W}$ \\
\hline 7 & $/ 05 / 2017$ & female & 86 & 42 & hand picking & $43^{\circ} 22^{\prime} 40^{\prime \prime} \mathrm{N}-5^{\circ} 47^{\prime} 15^{\prime \prime} \mathrm{W}$ \\
\hline
\end{tabular}




\section{Epibionts and associated species}

Ectosymbiotic microorganisms were found on the surface of the carapace and appendages of all redclaw crayfish specimens studied $(\mathrm{N}=7)$. Ciliate protozoans were the most abundant group being represented by the genera Epistylis, Vorticella and Zoothamnium. Other epibionts found were bdelloid rotifers, nematodes and naidid oligochaetes (the latter two groups were found only among the pleopods and the gills). Surprisingly, neither Epistylis ciliates nor bdelloid rotifers were found in the 15 red swamp and 15 signal crayfishes examined that lived sympatrically with the redcalw in the Nora River. This suggests that the Epistylis spp. and the rotifers found may be specific epibionts of the redclaw crayfish. Ciliate protozoans of the genus Epistylis are commonly found in native populations of the redclaw crayfish from Queensland (Australia) (Herbert, 1987).

Several viruses, bacteria, oomycetes, ciliate protozoans, platyhelminthes, branchiobdellid annelids and nematodes have been reported in the redclaw crayfish from its native distribution and/or their newly colonized areas (Herbert, 1987; Cannon, 1991; Mendoza et al., 2011; VNK, 2016). Some of them, like most common ciliates, are primarily considered as commensals and do not represent a major problem on the host in low densities (Herbert, 1987), whilst others as bdelloid rotifers constitute a high risk for the transmission of the white spot syndrome virus to other crayfish species (Longshaw, 2011).

Introduced specimens of the redclaw crayfish can also carry some of their own commensals and/or parasites. Some of them, like the Australian temnocephalidan platyhelminthes have been introduced to Africa and America and are generating great concern to conservationists (Volonteiro, 2009; Tavakol et al., 2016). In the same way that other introduced crayfish species acted as vectors of other invertebrate parasites in Europe (e.g., Vedia et al., 2015; Gelder \& Williams, 2016; Liuzzo et al., 2018), or the crayfish plague fungus, Aphanomyces astaci Schikora, transferred by red swamp and signal crayfishes to several European crayfish species (e.g., Martín-Torrijos et al., 2019).

\section{Invasive potential and possible impacts}

The native distribution area of the redclaw crayfish comprises the north of Australia (Queensland, Northern Territory) and the south of Papua New Guinea (Jones \& Gherardi, 2011). The species has been introduced in several countries from five continents, with feral (wild and allochthons) populations detected in Oceania (within Australia and in New Caledonia), America (Ecuador, Jamaica, Mexico, Paraguay, Puerto Rico and USA), Africa (Mozambique, South Africa, Swaziland, Zambia and Zimbabwe), Asia (China, Israel, Japan, Malaysia, Singapore, Taiwan and Thailand) and Europe (see below) (Jones \& Gherardi, 2011; Nunes et al., 2017 and references there in).

Records of isolated specimens of the redclaw crayfish have been repeatedly reported in Europe during the last decade (Kouba et al., 2014; Füreder, 2016). One specimen was recorded in a pond from Wageningen, the Netherlands, in 2008 (Soes, 2008), another single specimen from England in 2009 (Holdich \& Sibley, 2009) and more recently, three female specimens were reported from three different locations each in Hungary (Weiperth et al., 2019). Furthermore, a seemingly breeding population was detected in Germany in 2005, but its presence was not detected again in later years (Holdich et al., 2009). Up to date, only one wild population of the redclaw crayfish is considered as established in Europe, occupying a thermal oxbow lake in Slovenia with low population numbers (e.g. 15 individuals captured in 200 trap nights, Jaklič \& Vrezec, 2011). As a tropical species, the redclaw crayfish invasive potential has been commonly considered low in temperate regions such as Europe, since temperature limits their reproduction (see discussion in VKM, 2016). In artificial laboratory conditions without refuges available, the mortality of the redclaw crayfish increased below 15-20 ${ }^{\circ} \mathrm{C}$ (Jones \& Gherardi, 2011; Veselý et al., 2015), however in earthen ponds from Israel the redclaw crayfish can survive with winter water temperatures below $10^{\circ} \mathrm{C}$ for several days (Karplus et al., 1998). This way, considering the former evidences and the fact that is one of most common species in aquarium trade in Europe (Chucholl, 
2013), several authors have treated the redclaw crayfish as a species of high risk of introduction and establishment in Mediterranean countries and South Europe (Souty-Grosset et al., 2006; Jones \& Gherardi, 2011; Holdich, 2009).

In the reach of Nora River where the redclaw crayfish was found several years, the minimum winter water temperature (slightly less than 10 ${ }^{\circ} \mathrm{C}$ ), can allow its survival during the cold season. During the spring and summer months, the maximum water temperature (over $20{ }^{\circ} \mathrm{C}$ ) is lower than the minimum of $22-23{ }^{\circ} \mathrm{C}$ (range $22-31{ }^{\circ} \mathrm{C}$ ) usually reported in literature as necessary to reproduction and to reach an optimal growth with aquaculture purposes (Jones, 2000; Lawrence \& Jones, 2002; Souty-Grosset et al., 2006; Jones \& Gherardi, 2011; Saoud et al., 2013). Nevertheless, the Nora River temperature range $\left(10-20^{\circ} \mathrm{C}\right)$ falls within the tolerance range of the redclaw crayfish in the wild (i.e. $10-35{ }^{\circ} \mathrm{C}$ : Jones \& Gherardi, 2011), and may allow the survival and reproduction of this crayfish in northern Iberia, although in suboptimal conditions. However, several episodes of introduction from different years cannot be ruled out, since this location is a periurban reach surroundings Oviedo, easily accessed by humans. Due to its proximity to the city, the Nora River suffers introductions of NIS derived from recreational fishing (e.g. the red swamp and signal crayfishes) and/or aquarium release. This later is apparently the case of an established population of the giant ramshorn snail Marisa cornuarietis (L.) (Arias \& Torralba-Burrial, 2014). Indeed, trade of ornamental aquatic pets has been considered one of the main pathways of crayfish introductions into Europe, explaining most of the cases of feral specimens in natural environments (Chucholl, 2013), including the introduction of the species in northern Iberia herein documented. Outside Europe, redclaw crayfish established wild populations are introduced via either aquarium-trade, due to multiple releases from home aquaria (e.g. feral populations from Singapore: Ahyong \& Yeo, 2007) or aquaculture intentional or unintentional releases from holding aquaculture facilities (e.g. introduced populations in the Caribbean drainage of Costa Rica: Azofeifa-Solano et al., 2017, or in several African countries: Nunes et al., 2017).
The occurrence of three species of alien crayfishes in the same locality, accompanied by other aquatic alien species from different continents, represents the opening of new relationships in the ecological theater with uncertain results. We have not found data on direct competition between the redclaw crayfish and either red swamp or signal crayfish in the scientific literature, although it may happen. Moreover, the presence of the two American crayfish species in the Nora River could limit the invasive potential of redclaw crayfish, since both American species can transmit the pathogen Aphanomyces astaci, and the redclaw crayfish is known to be vulnerable to aphanomycosis disease (Marino et al., 2014). At this new locality, the combination of unfavorable conditions, of both abiotic (i.e. temperature) and biotic (i.e. presence of other alien crayfish species and their parasites) nature, may limit their invasive potential. The Nora river specimens are relatively small and no brooder females were detected, therefore it cannot be confirmed that they constitute a reproductively active population. It is known that the redclaw crayfish reaches sexual maturity between 6 to 12 months after hatching and its life span is 4-5 years long (Jones \& Gherardi, 2011). However, although the species has been consecutive detected during over 4 years at the same locality, it seems unlikely that all specimens came from a single introduction event. The repeated findings of redclaw crayfish specimens most likely result from several episodes of escape or release of crayfishes from domestic aquaria and ponds.

In the context of global warming, the intentional or unintentional release of ornamental crayfish species is especially troubling since temperature thresholds for the acclimatization and reproduction of warm water species may be reached in areas that were originally unsuitable, such as our study area in the Nora River. Although this new locality does not seem to represent an optimal habitat for this species, the almost continuous presence of the redclaw crayfish since 2013 may lead to an important risk to the ecosystem health, if their epibionts act as carriers of disease in native arthropods or other invertebrates. The commensal organisms of the redclaw crayfish, mainly the ciliate protozoans of 
presumably foreign origin (although this remains to be further studied), may switch to new crayfish or arthropods hosts in the Nora River. It is well-known that the release, even on a small-scale, of pathogens has the potential not only to spread but also for increasing its local population, thus becoming a largescale problem (Elliott, 2003; Greenberg \& Palen, 2019).

Control programs and a detailed monitoring of the evolution of the redclaw crayfish in the Nora River should be undertaken in order to establish the status of this species in this region and to evaluate the possible adverse effects that it may generate. As previously suggested by Holdich et al. (2009), we also consider that citizenship education, including primary school levels, recreational fishing organizations and aquarium hobbyists, into the dangers of spreading of NIS or exotic crayfish should be undertaken as a way to protect local freshwater biodiversity and also the indigenous crayfish species.

\section{ACKNOWLEDGEMENTS}

This work was funded by the Project PAPI-19-EMERG-26 (University of Oviedo). We would like to thank Hannelore Paxton for the English editing of the text, two anonymous reviewers for their helpful comments and Confederación Hidrográfica del Cantábrico (CHC) for providing the physicochemical data of the Nora River.

\section{REFERENCES}

AHYONG, S. T. \& D. C. J. YEO. 2007. Feral populations of the Australian red-claw crayfish (Cherax quadricarinatus von Martens) in water supply catchments of Singapore. Biological Invasions, 9: 943-946. DOI: 10.1007/ s10530-007-9094-0

ARIAS, A., \& A. TORRALBA-BURRIAL. 2014. First European record of the giant ramshorn snail Marisa cornuarietis (Linnaeus, 1758) (Gastropoda: Ampullariidae) from northern Spain. Limnetica, 33: 65-72. DOI: $10.23818 /$ limn.33.06

AZOFEIFA-SOLANO, J. C. \& B. NARANJO-ELIZONDO, A. H. ROJAS-CARRANZA
\& M. CEDEÑO-FONSECA. 2017. Presence of the Australian redclaw crayfish Cherax quadricarinatus (von Martens, 1868) (Parastacidae, Astacoidea) in a freshwater system in the Caribbean drainage of Costa Rica. BioInvasions Records, 6 (4): 351-355. DOI: 10 . 3391/bir.2017.6.4.08

BENEJAM L., S. SAURA-MAS \& A. SAPERAS. 2011. First record of the spiny-cheek crayfish Orconectes limosus (Rafinesque, 1817) introduced to the Iberian Peninsula. Aquatic Invasions, 6, Suppl. 1: S111-S113. DOI: 10.3391/ai.2011.6.S1.025

CANNON, L. R. G. 1991 Temnocephalan symbionts of the freshwater crayfish Cherax quadricarinatus from northern Australia. Hydrobiologia, 227: 341-347. DOI: 10.1007/ BF00027620

CLAVERO, M., C. NORES, S. KUBERSKY-PIREDDA \& A. CENTENO-CUADROS. 2016. Interdisciplinary to reconstruct historical introductions: solving the status of cryptogenic crayfish. Biological Reviews, 91(4): 1036-1049. DOI: 10.1111/brv.12205

CHUCHOLL, C. 2013. Invaders for sale: trade and determinants of introduction of ornamental freshwater crayfish. Biological Invasions, 15: 125-141. DOI: 10.1007/s10530-012-0273-2

ELLIOTT, M. 2003. Biological pollutants and biological pollution e an increasing cause for concern. Marine Pollution Bulletin, 46: 275-280. DOI: 10.1016/S0025-326X(02) 00423-X

FÜREDER, L. 2016. Crayfish in Europe Biogeography, Ecology and Conservation. In: Freshwater crayfish, a global overview. Kawai, T., Z. Faulkes \& G. Scholtz (eds.): 595-627. CRC Press, Boca Raton, FL. USA.

GELDER, S. R. \& B. W. WILLIAMS. 2016. Global Overview of Branchiobdellida (Annelida: Clitellata). In: Freshwater crayfish, a global overview. Kawai, T., Z. Faulkes \& G. Scholtz (eds.): 628-653. CRC Press, Boca Raton, FL. USA.

GREENBERG, D. A. \& W. J. PALEN. 2019. A deadly amphibian disease goes global. Science, 363: 1386-1388.

HERBERT, B. 1987. Notes on diseases and epibionts of Cherax quadricarinatus and $C$. 
tenuimanus (Decapoda: Parastacidae). Aquaculture, 64: 165-173. DOI: 10.1016/0044-8486 (87)90322-X

HOLDICH, D. M. 2009. Identifying crayfish in British waters. In: Crayfish Conservation in the British Isles, Proceedings of conference held in Leeds. Brickland J., Holdich D.M. \& Imhoff E.M. (eds.): 147-164.

HOLDICH D. M. \& P. J. SIBLEY. 2009. ICS and NICS in Britain in the 2000s. In: Crayfish Conservation in the British Isles, Proceedings of conference held in Leeds. Brickland, J., Holdich, D.M. \& Imhoff, E.M. (eds.): 13-33.

HOLDICH D. M., J. D. REYNOLDS, C. SOUTY-GROSSET \& P. J. SIBLEY. 2009. A review of the ever increasing threat to European crayfish from non-indigenous crayfish species. Knowledge and Management of Aquatic Ecosystems, 394-395, 11. DOI: 10.1051/kmae $/ 2009025$

JAKLIČ, M. \& A. VREZEC. 2011. The first tropical alien crayfish species in European waters: the redclaw Cherax quadricarinatus (Von Martens, 1868) (Decapoda, Parastacidae). Crustaceana, 84: 5-6. DOI: 10.1163/ 001121611 X577936

JONES, C. M. (ed.) 2000. Recommended Practices for Redclaw Crayfish Aquaculture based on Research and Development Activities, 1988 through 2000. Queensland Government. Department of Primary Industries and Fisheries, Cairns, Australia.

JONES, C. \& F. GHERARDI. 2011. Cherax quadricarinatus (redclaw crayfish). In: Invasive Species Compendium. CAB International, Wallingford, UK. https://www.cabi.org/ isc/datasheet/89135

KARPLUS, I., M. ZORAN, A. MILSTEIN, S. HARPAZ, Y. ERAN, D. JOSEPH \& A. SAGI. 1998. Culture of the Australian red-claw crayfish (Cherax quadricarinatus) in Israel: III. Survival in earthen ponds under ambient winter temperatures. Aquaculture, 166(3-4): 259-267. DOI: 10.1016/S0044-8486 (98)00290-7

KOUBA, A., A. PETRUSEK, \& P. KOZÁK. 2014. Continental-wide distribution of crayfish species in Europe: update and maps. Knowledge and Management of Aquatic
Ecosystems, 413: 05. DOI: 10.1051/kmae/ 2014007

LAWRENCE, C. \& C. JONES. 2002. Cherax. In: Biology of Freshwater Crayfish. Holdich, D. M. (Ed.): 645-666. Blackwell Science, UK.

LIUZZO, M., G. ALFONSO, E. BELI, M. ARCULEO \& F. MARRONE. 2018. First record of the alien leech Myzobdella lugubris Leidy, 1851 (Hirudinea, Piscicolidae) in the Palearctic. Limnetica, 37: 311-318. DOI: 10.23818/limn. 37.25

LONGSHAW, M. 2011. Diseases of crayfish: A review. Journal of Invertebrate Pathology, 106: 54-70. DOI: 10.1016/j.jip.2010.09.013

MARINO, F., T. PRETTO, F. TOSI, S. MONACO, C. DE STEFANO, A. MANFRIN \& F. QUAGLIO. 2014. Mass mortality of Cherax quadricarinatus (von Martens, 1868) reared in Sicily (Italy): crayfish plague introduced in an intensive farming. Freshwater crayfish, 20(1): 93-96. DOI: 10.5869/fc.2014. v20-1.93

MARTÍN-TORRIJOS, L., H. KOKKO, J. MAKKONEN, J. JUSSILA \& J. DIÉGUEZ-URIBEONDO. 2019. Mapping 15 years of crayfish plague in the Iberian Peninsula: The impact of two invasive species on the endangered native crayfish. PLOS ONE, 14(8): e0219223. DOI: 10.1371/journal.pone. 0219223

MATALLANAS, B., M. D. OCHANDO, F. ALONSO \& C. CALLEJAS. 2016. Update of genetic information for the white-clawed crayfish in Spain, with new insights into its population genetics and origin. Organisms Diversity \& Evolution, 16(3): 533-547. DOI: 10.1007/s13127-016-0268-4

MENDOZA, R., G. RODRÍGUEZ \& S. CASTILLO. 2011. Riesgo de dispersión y posibles impactos de los acociles australianos del género Cherax en México. Comisión Nacional para el Conocimiento y Uso de la Biodiversidad. México, D.F.

NUNES, A. L., T. A. ZENGEYA, A. C. HOFFMAN, G. J. MEASEY \& O. L. F. WEYL. 2017. Distribution and establishment of the alien Australian redclaw crayfish, Cherax quadricarinatus, in South Africa and Swaziland. PeerJ, 5: e3135. DOI: 10.7717/peerj.3135 
OFICIALDEGUI, F. J., M. CLAVERO, M. I. SÁNCHEZ, A. J. GREEN, L. BOYERO, T. C. MICHOT, K. KLOSE, T. KAWAI \& C. LEJEUSNE. 2019. Unravelling the global invasion routes of a worldwide invader, the red swamp crayfish (Procambarus clarkii). Freshwater Biology, 64: 1382-1400. DOI: 10.1111/fwb. 13312

PÖCKL, M., D. M. HOLDICH, J. PENNERSTORFER. 2006. Identifying native and alien crayfish species in Europe. European Project Craynet Publication, Poitiers, France.

RICCIARDI, A. \& H. J. MACISAAC. 2011. Impacts of biological invasions on freshwater ecosystems. In: Fifty years of invasion ecology: the legacy of Charles Elton. D.M. Richardson (ed.): 211-224. Wiley-Blackwell, Oxford, UK.

SAOUD, I. P., J. GHANAWI, K. R. THOMPSON \& C. D. WEBSTER. 2013. A review of the culture and diseases of redclaw crayfish Cherax quadricarinatus (von Martens 1868). Journal of the World Aquaculture Society, 44: 1-29.

SOES, D. M. 2008. Een vondst van de Australische roodklauwkreeft (Cherax quadricarinatus) in Nederland. Kreeften nieuwsbrief, 2: 7-8.

SOUTY-GROSSET, C., D. M. HOLDICH, P. Y. NOÉL, J. D. REYNOLDS \& P. HAFFNER (eds.). 2006. Atlas of crayfish in Europe. Muséum national d'Histoire naturelle, Paris, France.

TAVAKOL, S., W. J. LUUS-POWELL, W. J. SMIT, C. BAKER, A. HOFFMAN \& A. HALAJIAN. 2016. First introduction of two Australian temnocephalan species into Africa with an alien host: double trouble. Journal of Parasitology, 102: 653-659. DOI: 10.1645/
$15-936$

TORRALBA-BURRIAL, A. \& F. J. OCHARAN. 2013. Iberian Odonata distribution: data of the BOS Arthropod Collection (University of Oviedo, Spain). ZooKeys, 306: 37-58. DOI: 10.3897/zookeys.306.5289

VEDIA, I. \& R. MIRANDA 2013. Review of the state of knowledge of crayfish species in the Iberian Peninsula. Limnetica, 32: 269-286. DOI: $10.23818 /$ limn.32.22

VEDIA, I., J. OSCOZ, J. RUEDA, R. MIRANDA, E. M. GARCÍA-ROGER, E. BAQUERO \& S. R. GELDER. 2015. An alien ectosymbiotic branchiobdellidan (Annelida: Clitellata) adopting exotic crayfish: a biological co-invasion with unpredictable consequences. Inland Waters, 5: 89-92. DOI: 10.5268/IW5.1 .799

WEIPERTH, A., B. GÁL, P. KUŘÍKOVÁ, I. LANGROVÁ, \& A. KOUBA. 2019. Risk assessment of pet-traded decapod crustaceans in Hungary with evidence of Cherax quadricarinatus (von Martens, 1868) in the wild. North-Western Journal of Zoology, 15: 42-47. VÁZQUEZ, F. J. 2003. Estudio de la diferenciación y madurez sexual en la langosta de agua dulce, Cherax quadricarinatus (Decapoda, Astacidea, Parastacidae) y su aplicación en acuicultura. $\mathrm{PhD}$ Thesis, Universidad de Buenos Aires, 123 pp.

VOLONTERIO, O. 2009. First report of the introduction of an Australian temnocephalidan into the New World. Journal of Parasitology, 95: 120-123. DOI: 10.1645/GE-1726.1

VKM. 2016. Risk assessment on import of Australian redclaw crayfish to Norway, Opinion of the Panel on Animal Health and Welfare, Oslo, Norway. 